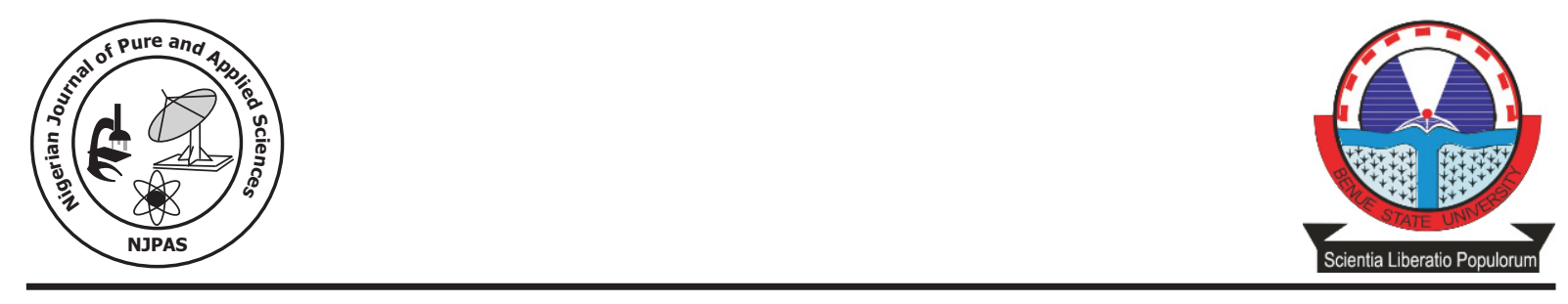

\title{
Malaria Parasites and Packed Cell Volume of Free Range Poultry in Abeokuta metropolis, Ogun State, Nigeria.
}

\author{
${ }^{1}$ Sam-Wobo, S. O., ${ }^{1}$ Malumi, O. O., ${ }^{2}$ Mafiana,C. F. ${ }^{3}$ Oganah, B. C. and ${ }^{1}$ Surakat, O. A. \\ ${ }^{1}$ Department of Biological Sciences, Federal University of Agriculture, Abeokuta; \\ ${ }^{2}$ Executive Secretary Office, National University Commission, Abuja, Nigeria. \\ ${ }^{3}$ Department of Home Economics, AdeniranOgunsanya College of Education, Oto-ljanikin, Lagos
}

\begin{abstract}
Malaria parasites and packed cell volume offree range poultry was conducted on one hundred free range chickens collected from three communities in Abeokuta (Osiele, Lafenwa and Kuto). The results revealed that out of the 100 free range chickens examined, 13(13\%) were infected with avian malaria parasite. Hematological parameter i.e. packed cell volume (PCV) revealed that chicken with PCV range 16-20 were $33.33 \%$ positive for malaria parasite. Others between PCV ranges $21-25$ were $33.3 \%$, while those between PCV ranges of $26-30$ were $16.66 \%$ and those with PCV range of $31-35$ were $16.67 \%$.Chi-square analysis showed a significant difference between packed cell volume and malaria parasite $(p<0.05)$. However, no significant difference was observed between sex and malaria parasite $(p>0.05)$. The presence of avian malaria parasites in the study area could be of some epidemiological implications since the infected poultry could act as reservoir for malaria parasites.
\end{abstract}

Keywords: Malaria Parasites, Packed Cell Volume, Poultry, Abeokuta, Ogun State.

\section{Introduction}

Poultry production has undergone changes during the past decades, due to the introduction of modern intensive production methods, new breeds and improved biosecurity and preventive health measures (FAO, 1995). However, in developing countries, the adoption of this type of production has been limited and therefore progress in industrial poultry production methods has had little effect on subsistence poultry production in the rural and peri-urban areas (Permin and Bisgaard, 2000). In Nigeria, access to poultry meat and eggs depends on subsistence level poultry production. Sonaiya and Gueye (1998) estimated that family poultry system accounts for about $94 \%$ of the total poultry produce in Nigeria. Local chickens are kept mainly in rural and peri-urban areas where the birds scavenge in and around the compound of households, feeding on the locally available resources e.g. earthworm, house refuse, insects and residues of harvest (Dienget al; 1998). Owing to the free range and scavenging habits, traditional village poultry thus appears to be in permanent contact with soil and insects. Soil, especially when humid and warm may serve as an important reservoir and transmission site for larval stages of helminthes. Also, some insects, which may act as vectors for protozoans are favoured by high temperature and humidity (Pandey, et al; 
1992). Perminet al; (1997) noted that majority of chickens are parasitized throughout the year with two or more species of parasites, thus raising the awareness that loss from parasitic diseases in African rural poultry operations could be very alarming.

Avian malarial infections are caused by parasites of the genus Plasmodium. Transmission is by mosquitoes. About 65 species of Plasmodium from over 1000 different birds have been described (Kemp, 1978). The species pathogenic for domestic fowl are found mostly in Asia, Africa and South America. Malaria outbreaks in birds on the North American continent are sometimes found in species of the order Anseriformes, Passeriformes and Columbiformes. Although many species of Plasmodium can be introduced into various domestic fowl, only a few appear to be natural parasites of these birds. P. gallinaceum occurs in jungle fowl and domestic hens; $P$. juxtanucleare parasitizes domestic hens and turkeys; $P$. duraeand $P$. griffithsi occur in turkeys.P. lophurae of the fire-backed pleasant can also parasitize chickens and has been host adapted to other domestic fowls and ducks, P. tallaxof the guinea fowl has been adapted to various domestic fowl, $P$. hermani will infect domestic and wild turkeys and bobwhite quail (Forrester et al, 1987).

The pathologic effects in avian hosts range from no apparent signs to severe anaemia and death. $P$. gallinaceum, $P$. juxtanucleare, and $P$. durae are the most pathogenic for domestic fowl and may cause $90 \%$ mortality. Intense and severe anaemia and generalized hypoxia may occur in $P$. gallinaceum malaria (Kemp, 1978). A similar situation occurs in ducks affected with $P$. lophurae. Severe anaemia may also occur in $P$. juxtanucleare infections. Other pathologic manifestations that occur in avian malaria for example,the exo-erythrocytic stages of $P$. gallinaceum may block capillaries in the brain, resulting in death due to central narrow system dysfunction.P. durae, which can cause high mortality in turkeys, causes extensive fibrosis in many tissues.

Haematological evaluation is a valuable tool in measuring the physiological responsiveness of the animal to its environment and in the diagnosis of many diseases. Therefore the study was carried out to determine malaria parasites and packed cell volume on free range poultry in Abeokuta.

\section{Materials and Methods}

The local free range population studied comprised flocks of peri-urban and urban scavenging poultry in Abeokuta. One hundred birds were examined between August and October 2005 and both adult and immature chickens were studied. The chickens were collected during the day from Kuto, Osiele and Lafenwa markets respectively and then transported to the laboratory at the Department of Biological Sciences, Federal University of Agriculture Abeokuta where physical and haematological examinations were carried out.Body weight was measured by means of a weighing balance and the chickens were classified as light weight (150g-300g), medium weight (301g-450g) and heavy weight (451g and above).

For sex determination, the nature of their comb was used as a distinguishing factor (Oluyemi and Roberts, 1979). Females had smaller and shorter combs while males had larger and longer combs.

\section{Packed Cell Volume (PCV)}

In determining the PCV of the chickens, blood samples were obtained immediately the birds were slaughtered and collected into labeled bottles containing ethylene diaminetetracetate (EDTA). Samples were examined for PCV in the laboratory using the microhaematocrit method (Coles, 1974).

\section{Examination of Slide for Malaria Parasite}

Thin films were prepared and the slides were then examined for Malaria parasites. Identification of the parasites was based on parameters described by Mandal (1990), Nassar (1992) and Sonnenshine (1993). 


\section{Data Analysis}

Data from blood samples were analyzed using SPSS version 16. The data generated from this study were presented using descriptive statistics. Chi-square was used to obtain level of significant $(p<0.05)$.

\section{Results}

The result on the distribution of chicken based on sex and body colour of chicken from the 3 different market locations is presented in table 1. More pattern coloured birds were encountered than other colour types and chisquare statistical analysis showed a significant difference $(p<0.05)$ between sex and body colour.

The distribution of the parasitized birds with respect to parasite count, sex, weight, packed cell volume and location is presented in table 2. Thirteen percent of the birds had malaria parasite (Plasmodium gallinaceum). The parasites were observed in 3 birds from Kuto, 4 birds from Osiele and 6 birds from Lafenwa market.

All 3 chickens from Kuto were female, 2 birds had moderate count, one had mild count, 3 birds were also medium weight while one lightweight. 3 out of the 4 birds from Osiele were male and all had mild count, 1 bird was heavy weight, 1 was lightweight while 2 birds were medium weight. Of the 6 parasitized birds from Lafenwa, 2 were male, 4 were female, and one had a moderate count while the rest had light count. Also, all the birds were heavy weight birds.

\section{Distribution of the Chickens Based On Sex and Malaria Parasite}

The results in table 3 shows that $5 \%$ of the male chickens were positive for malaria parasite and $8 \%$ of the female chickens were also positive. Chi-square analysis reveals that there is no significant difference $(\mathrm{P}>0.05)$ in infection among the sexes of the chickens from the 3 communities where they were obtained.
Distribution of the Chickens Based On Packed Cell Volume and Malaria Parasite

The result in table 4 shows the distribution of the chicken based on packed cell volume and malaria parasite. Chickens with PCV ranging from 10-15 are not positive for malaria parasite, those between 16-20 are $4 \%$ positive, $21-25$ are $5 \%$ positive, $26-30$ are $2 \%$ positive, $31-35$ are $2 \%$ positive for malaria parasite. Chi-square reveals a significant difference $(\mathrm{P}<0.05)$ between packed cell volume and malaria parasite.

\section{Distribution of the Birds Based On Sex and Packed Cell Volume}

From the result, table 5 presents the distribution of chickens based on sex and packed cell volume. Birds with PCV ranging from $10-15$ were ranging from $10-15$ were $2 \%$ male, $4 \%$ female, those ranging from $16-20$ were $1 \%$ male, $6 \%$ female; those ranging from 21-25 were $19 \%$ male, $24 \%$ female, those ranging from $26-30$ were $11 \%$ male, $18 \%$ female, those ranging from $31-35$ were $6 \%$ male, $6 \%$ female and those with PCV above 35 were $2 \%$ male, $1 \%$ female. Also, statistical analysis using the linear by linear association reveals a significant difference $(\mathrm{P}<0.05)$ between sex and packed cell volume.

\section{Distribution of the Chickens Based On Malaria Parasite and Body Colour}

The result in table 6 shows the distribution of chicken based on Malaria parasite and body colour. Chickens with pattern body colour had a prevalence of $7(53.85 \%)$, brown colour were $2(15.38 \%)$, black were $2(15.38 \%)$, white colour chicken were $1(7.69 \%)$ and light brown were $1(7.69 \%)$. Chi-square analysis shows that there is no significant difference between malaria parasite and body colour of the chickens.

\section{Distribution of the Chickens Based On Packed Cell Volume and Body Colour}

The result in table 7 shows the distribution of chickens based on packed cell 
volume and body colour. Chickens with PCV ranging from $10-15$ were pattern $1(16.67 \%)$, Brown $3(50 \%)$ and white 2(33.33\%) respectively. Those with PCV range of 16-20 were pattern 3(42.86\%), Brown 1(14.29\%), black 2(28.57\% and white 1(14.29\%). Chickens with PCV range of 21-25 were pattern 19(44.19\%), brown 6(13.95\%), black $10(23.26 \%)$ and white $8(18.60 \%)$. Those with PCV range 26-30 were pattern 18(62.07\%), brown 2(6.89\%), black 4(13.79\%, white $3(10.34 \%)$, grey $1(3.45 \%)$ and dark brown $1(3.45 \%)$. Chickens with PCV range of 31-35 were pattern $7(58.33 \%)$, black $4(33.33 \%)$ and right brown $1(8.33 \%)$. While chickens with PCV range above 35 were pattern 2(66.67\%) and black $1(33.33 \%)$ respectively. Chi-square analysis reveals no significant difference $(\mathrm{P}>0.05)$ between packed cell volume and body colour.

Table 1: Distribution of birds from the 3 different locations based on sex and body colour.

\begin{tabular}{lcccccccr}
\hline $\begin{array}{l}\text { Sex/body } \\
\text { colour }\end{array}$ & & & & & \multicolumn{5}{c}{ Dark brown } \\
\hline Male & $25(60.97)$ & $5(12.20)$ & $8(19.51)$ & $2(4.88)$ & 0 & 0 & $1(2.44)$ & 41 \\
Female & $25(42.37)$ & $7(11.86)$ & $13(22.03)$ & $12(20.34)$ & $1(1.69)$ & $1(1.69)$ & 0 & 59 \\
Total & 50 & 12 & 21 & 14 & 1 & 1 & 1 & 100 \\
\hline
\end{tabular}

Table 2: The number of parasitized birds with respect to their level of parasitaemia, sex, weight, PCV and location.

\begin{tabular}{cclclll}
\hline & SERIAL & & & & \\
& NUMBER & LOCATION & COUNT & SEX & WEIGHT & PCV \\
\hline 1 & & & & & 354.8 \\
2 & K16 & KUTO & + & FEMALE & (medium) & 25 \\
3 & K19 & KUTO & ++ & FEMALE & 258 (light) & 18 \\
4 & K32 & KUTO & ++ & FEMALE & 443 (medium) & 34 \\
5 & OS12 & OSIELE & + & FEMALE & 560.4 (heavy) & 30 \\
& OS16 & OSIELE & + & FEMALE & 250.1 (light) & 24 \\
6 & & & & 304.5 & \\
7 & OS17 & OSIELE & + & MALE & (medium) & 29 \\
8 & OS30 & OSIELE & + & MALE & 430 (medium) & 23 \\
9 & L3 & LAFENWA & ++ & FEMALE & 496.3 (heavy) & 24 \\
10 & L6 & LAFENWA & + & MALE & 510.7 (heavy) & 31 \\
11 & L7 & LAFENWA & + & FEMALE & 530.4 (heavy) & 24 \\
12 & L16 & LAFENWA & + & FEMALE & 521 (heavy) & 19 \\
13 & L17 & LAFENWA & + & FEMALE & 513.5 (heavy) & 20 \\
\hline
\end{tabular}

Light weight (150g-300g), medium weight (301g-450g) and heavy weight (451g and above)

Table 3: Distribution of all the chickens from Kuto, Osiele and Lafenwa based on sex and malaria parasite.

\begin{tabular}{llcr}
\hline Sex & \multicolumn{2}{l}{ Malariaparasite } & \multicolumn{2}{l}{ total } \\
& positive & negative & 41 \\
Male & $5(5 \%)$ & $36(36 \%)$ & 59 \\
Female & $8(8 \%)$ & $51(51 \%)$ & 100 \\
& 13 & 87 & \\
\hline
\end{tabular}


Table 4: Distribution of the birds from the 3 mark et locations based on packed cell volume and malaria parasite.

\begin{tabular}{|c|c|c|c|}
\hline & $\begin{array}{l}\text { Malaria } \\
\text { parasite }\end{array}$ & & \\
\hline $\begin{array}{l}\text { Packed Cell Volume } \\
\text { (PCV) }\end{array}$ & Positive (\%) & Negative(\%) & Total \\
\hline $10-15$ & $0(0 \%)$ & 6 & 6 \\
\hline $16-20$ & $4(30.76 \%)$ & 3 & 7 \\
\hline $21-25$ & $5(38.46 \%)$ & 38 & 43 \\
\hline $26-30$ & $2(15.38 \%)$ & 27 & 29 \\
\hline $31-35$ & $2(15.38 \%)$ & 10 & 12 \\
\hline \multirow[t]{2}{*}{$36-40$} & $0(0 \%)$ & 3 & 5 \\
\hline & 13 & 87 & 100 \\
\hline
\end{tabular}

Table 5: Distribution of birds based on sex and packed cell volume

\begin{tabular}{lccc}
\hline Packed cell volume & \multicolumn{2}{c}{ sex } \\
& Frequency & Male & Female \\
\hline $10-15$ & 6 & 2 & 4 \\
$16-20$ & 7 & 1 & 6 \\
$21-25$ & 43 & 19 & 24 \\
$26-30$ & 29 & 11 & 18 \\
$31-35$ & 12 & 6 & 6 \\
$>35$ & 3 & 2 & 1 \\
& 100 & 41 & 59 \\
\hline
\end{tabular}

Table 6: Distribution of malaria parasite by Body colour

\begin{tabular}{lcc}
\hline & $\begin{array}{l}\text { Malaria } \\
\text { parasite } \\
\text { Pody colour }\end{array}$ & \\
\hline Pattern & $7(53.85 \%)$ & 43 \\
Brown & $2(15.38 \%)$ & 10 \\
Black & $2(15.38 \%)$ & 19 \\
White & $1(7.69 \%)$ & 13 \\
Light brown & $1(7.69 \%)$ & 0 \\
Grey & $0(0 \%)$ & 1 \\
Dark Brown & $0(0 \%)$ & 1 \\
& 13 & 87 \\
\hline
\end{tabular}

Table 7: Distribution of PCV values by body colour

\begin{tabular}{l|c|ccccccc}
\hline \multicolumn{2}{l|}{ Packed Cell Volume } & \multicolumn{2}{c}{$\begin{array}{l}\text { body } \\
\text { colour }\end{array}$} \\
\hline & frequency & 1 & 2 & 3 & 4 & 5 & 6 & 7 \\
\hline 1015 & 6 & $1(16.67 \%)$ & $3(50 \%)$ & 0 & $2(33.3 \%)$ & 0 & 0 & 0 \\
$16-20$ & 7 & $3(42.86 \% 0$ & $1(14.29 \%)$ & $2(28.57 \%)$ & $1(14.29 \%)$ & 0 & 0 & 0 \\
$21-25$ & 43 & $19(44.19 \%)$ & $6(13.95 \%)$ & $10(23.26)$ & $8(18.60 \%)$ & 0 & 0 & 0 \\
$26-30$ & 29 & $18(62.07 \%)$ & $2(6.89 \%)$ & $4(13.79 \%)$ & $3(10.34 \%)$ & 0 & $1(3.45 \%)$ & $1(3.45 \%)$ \\
$31-35$ & 12 & $7(58.33 \%)$ & 0 & $4(33.33 \%)$ & 0 & $1(8.33 \%)$ & 0 & 0 \\
$>35$ & 3 & $2(66.67 \%)$ & 0 & $1(33.33 \%)$ & 0 & 0 & 0 & 0 \\
& 100 & 50 & 12 & 21 & 14 & 1 & 1 & 1 \\
\hline
\end{tabular}




\section{Discussion}

A total of one hundred (100)free range chickens were collected from three communities in Abeokuta (Osiele, Lafenwa and Kuto), to examine them for malaria parasites. The results on distribution of the chickens based on sex and body colour reveals that male birds $(60.97 \%)$ were more coloured than female birds (42.37\%), however they were not statistically significant $(\mathrm{P}<0.05)$. The results on the level of parasitaemia revealed that $13 \%$ of the chickens were positive, for the avian malaria parasite. The statistical analysis reveals that there is no significant difference $(\mathrm{P}>0.05)$ between malaria parasite and sex. This means that the malaria parasite is independent of sex, and that the mosquito will site any free-range chicken irrespective of sex.

The distribution of the chickens based on malaria parasite (MP) and packed cell volume (PCV) of the range chickens revealed varying ranges,21-25 had the highest prevalence( $38.46 \%$ ), followed by those with PCV range of 16-20 whose prevalence was $30.76 \%$, and birds with PCV range between 26-30and 31-35 had the same prevalence $(15.38 \%)$ respectively.

In conclusion, Plasmodium gallinaceumwas observed to be the most prevalent haemoparasite and is considered to be highly pathogenic to the chickens with mortality risks in the range of $30-80 \%$ (Soulsby, 1982). Avian malaria can also constitute a health problem in poultry and also the avian species may act as a reservoir host for the human malaria parasite (Orajaka and Nweze (1991).It is advised that sanitary measures are followed in the commercial and semi-commercial systemsto reduce the transmission of these parasites. Further research to assess the impact of malaria parasite on production performance of the scavenging chickens including cost effectiveness of control strategies is suggested.

\section{References}

Coles, E. H. (1974). Veterinary Clinical Pathology, W. B. Sanders Company. London $2^{\text {nd }}$ Edition pp.99-114.

Dieng, A., Gueye, E. F Mahoungoli-Mouelle, N. $\mathrm{M}$, and Bulgen, A. (1998). Effect of diet and poultry species on feed intake and digestibility of nutrients in Senegal. INFPD Newsletter 8 (3): 6-13.

Food and Agriculture Organization (FAO). 1995. Animal Health Year Book, Rome, FAO.

Forrester, D. J., J. K Nagar and M. D Young. (1987). Natural infection of Plasmodium hermani in the Northern Bobwhite, Colnius virigianus in Florida. Journal of Parasitology 73: 865-866.

Kemp, R. R, B. W Calnek, C. F Helmbodt, W. M Reid and H. W Yodur Jr.(1978). Diseases of Poultry. $7^{\text {th }}$ Edition, Iowa State University Press, pp 824-825.

Mandal, F. B (1990). Seasoanal incidence of blood inhibiting Haemoproteus columbaekruse (Sporozoa: Haemoproteidae) in pigeons. Journal of. Animal Health., 29(1):29-35.

Nassar, A. M. (1992): Theileria infection in camels (Camelus dromedaries) in Egypt. Veterinary Parasitology., 43(1-2): 147149.

Oluyemi, J. A and Roberts F. A. (1979). Poultry production in warm climates. Macmillan Press Ltd. $1^{\text {st }}$ Edition, Hong Kong. 210 pages.

Orojaka, L. J., Nweze, L. C., (1991). Prevalence of Blood Protozoan Parasites of Avian species in Nsukka area of Anambra State, Nigeria. German Veterinary Journal.29:91-95.

Pandey, V. S. Demey, F. and Verhulst, A. (1992). Parasites diseases; a neglected problem In village poultry in Africa, Rabat, Morocco,pp 136-141.

Permin, A., Magwisha, H. Kassuku, A. A., Nnsen P., Bisgaard, M. Frandsen, F and Gibbons, 
L. (1997). A Cross sectional study of helminthes in rural scavenging poultry in Tanzania in relation to season and climates. Journal of Helminthology 71, 93:233-240.

Permin, A and Bisgaard, M (2000). A general review on some important disease in free range chickens.Proceedings of a workshop on poultry as a tool in poverty eradication and promotion in gender equalitypp 1-5.
Sonaiya, E. B and Gueye, E. B. (1998). The importance of family poultry: INFPD Newsletter 8 (2): 2-3.

Sonenshine, D. A. (1993). Biology of Ticks. Oxford Un iversity Press.

Soulsby. E. J. L. (1982). Helminths, Arthropods and protozoa of Domesticated Animals, $7^{\text {th }}$ edition.BaillereTindal, East Sussex,U.K 